\title{
EFFECT OF SLOW RELEASE NITROGEN FERTILIZERS ON PRODUCTIVITY AND QUALITY OF POTATO (Solanum tuberosum L.). \\ Ezzat, A. S. ${ }^{*}$ and A. M. Abd El-Hameed ${ }^{\star *}$ \\ * Vegetable Res. Dept., Hort. Res. Institute, Agric. Res. Center \\ ** Plant Nutrition Dep., Soil, Water and Environment Res. Institute, Agric. Res. Center
}

ABSTRACT

The present investigation was carried out at Baramoon Research Station, Mansoura, Dakahlia Governorate, Egypt (+ $7 \mathrm{~m}$ altitude, $30^{\circ} 11^{-}$latitude and $28^{\circ} 26$ longitude), during Nili seasons of 2007/08 and 2008/09, to study the effect of slow release-N (urea formaldehyde "UF"; Sulfur coated urea "SCU", and compost) as compared with soluble-N (ammonium nitrate "AN") fertilizer on productivity, and quality of potato cv. Cara. The most important finding could be summarized as follows:

- Compost 9 ton fed ${ }^{-1}$ plus SCU3 $67.5 \mathrm{~kg} \mathrm{~N}_{\text {fed }}{ }^{-1}$ led to significant increase in all vegetative growth parameters of potato plants (plant height, leaf area/plant and dry weight/plant) in both seasons.

- Significant differences were detected in total tuber yield and yield components among various treatments in both seasons. Compost 9 ton fed $^{-1}+$ SCU3 $67.5 \mathrm{~kg} \mathrm{~N} \mathrm{fed}^{-1}$ and SCU1 $135 \mathrm{~kg} \mathrm{~N}^{-1}$ had significant effect in this respect.

- Application of Compost 9 ton fed ${ }^{-1}+$ SCU3 $67.5 \mathrm{~kg} \mathrm{~N}^{-1}{ }^{-1}$ significantly increased tuber dry matter (in both season), starch and specific gravity of tuber $\left(1^{\text {st }}\right.$ season, only) and significantly decreased nitrate and nitrite content of tuber (both season), in comparison with other treatments.

- The NPK \% of potato tubers in treatment amended with Compost 9 ton $\mathrm{fed}^{-1}+$ SCU3 $67.5 \mathrm{~kg} \mathrm{~N}^{-1}{ }^{-1}$ was higher than with other treatments in two seasons. On the other hand, the greatest value of nitrogen use efficiency (NUE) was obtained by the application of SCU1 followed by UF2.

- The highest net return was obtained from potato receiving Compost 9 ton fed ${ }^{-1}+$ SCU3 $67.5 \mathrm{~kg} \mathrm{~N} \mathrm{fed}^{-1}$ in comparison with other treatments.

Generally, it could be concluded that, application of nitrogen fertilizer in the form of Compost at the rate of 9 ton fed $^{-1}+$ SCU3 $\left(67.5 \mathrm{~kg} \mathrm{~N}\right.$ fed $\left.^{-1}\right)$ in potato fields was the most effective treatment for satisfactory improvements in productivity and quality yields with keeping the health and safety of human and environment.

Keywords: Potato, slow release $\mathrm{N}$-fertilizers, soluble $\mathrm{N}$-fertilizers, productivity, costs.

\section{INTRODUCTION}

Nitrogen is the most limiting nutrient for crop production in many of the world's agricultural areas and its efficient use is important for the economic sustainability of cropping systems. Furthermore, the dynamic nature of $\mathrm{N}$ and its tendency for losing from soil-plant systems creates a unique and challenging environment for its efficient management. Crop response to applied $\mathrm{N}$ and use efficiency are important criteria for evaluating crop $\mathrm{N}$ requirements for maximum economic yield. Recovery of $\mathrm{N}$ in crop plants is usually less than $50 \%$ worldwide. Low recovery of $\mathrm{N}$ in annual crop is associated with its loss by volatilization, leaching, surface runoff, 
denitrification, and plant canopy. Low recovery of $\mathrm{N}$ is not only responsible for higher cost of crop production, but also for environmental pollution. Hence, improving $\mathrm{N}$ use efficiency (NUE) is desirable to improve crop yields, reducing cost of production, and maintaining environmental quality (Fageria and Baligar, 2005).

Besides, the steady increase in population growth and food demand and the continuous reduction in cultivated land per capita induce steady intensification of fertilizer application worldwide. Despite improvements in the practices of nutrient application, the use efficiency (UE) of essential elements such as $\mathrm{N}$ is not satisfactory, resulting in an increase of environmental problems. The use of controlled-release fertilizers (CRFs) starts to evolve as a promising direction offering an excellent means to improve management of nutrient application and by this reducing significantly environmental threats while maintaining high crop yields of good quality. Low cost effectiveness and limited recognition of the potential benefits to be gained from the CRFs were so far the main reasons for their limited consumption. (Shaviv, 2001; Fageria and Baligar; 2005 and Chien et al., 2009).

Improved efficiency of $\mathrm{N}$ may be achieved with controlling the dissolution of applied nitrogen fertilizers, development of compounds with limited water solubility, altering soluble materials to retard their release to the soil solution and with mechanical additives to control fertilizer-soil microbial reactions (Chatzoudis and Valkanas, 1995).

From the view point of improving nutrient recovery by plants, three main advantages are cited for controlled-release fertilizers:

1-Reduction of nutrient loss via leaching and runoff, Reduction of chemical and biological immobilization reaction in soils which cause plantunavailable form and for nitrogen, and Reduction of rapid nitrification and nitrogen loss through ammonia volatilization and denitrification (Fox et al., 1996).

In this respect, Allen (1984) mentioned that potential benefits from slow release fertilizers include: (i) more efficient use of nitrogen by the crop, (ii) less leaching of nitrogen, (iii) lower toxicity, (iv) longer lasting nitrogen supply, (v) reduced volatilization losses of nitrogen and (vi) lower application cost. Moreover, Liegel and Walsh (1976) reported that slow release SCU carriers produced higher yields and nitrogen recovery of potato than plants grown with urea or AN, because their dissolution reduced leaching losses of N. Also, they showed that frequent potato yield depressions with fast release $\mathrm{N}$ fertilizers, mainly due to $\mathrm{N}$ leaching. In another study, Waddell et al. (1999) reported that the use of unconventional $\mathrm{N}$ sources such as turkey manure and SCU are viable alternatives for potato production, SCU applied at the rate of $224 \mathrm{~kg} \mathrm{ha}^{-1} \mathrm{~N}$ produced maximum tuber yield under either drip or sprinkler irrigation. In field trials for three years, Hutchinson and Simonne (2003) demonstrated that $\mathrm{N}$ rates can be reduced with a controlled-release fertilizer program compared to a soluble $\mathrm{N}$ fertilizer program (non-coated urea and/or ammonium nitrate) without reducing crop yield or quality. Also, Pack (2004) found that all six controlled release fertilizers (CRF) with the $168 \mathrm{~kg} \mathrm{~N}$ ha $^{-1}$ rate, potatoes gave 3 to $14 \%$ higher marketable yield than the AN at the rate of $224 \mathrm{~kg} \mathrm{~N} \mathrm{ha}^{-1}$. Also at the rate of $224 \mathrm{~kg} \mathrm{~N} \mathrm{ha}^{-1}$, five CRFs produced 7 
to $36 \%$ higher marketable yield than with the AN. The objective of this study is to compare the slow release- $\mathrm{N}$ and traditional soluble- $\mathrm{N}$ fertilizers on productivity, quality, and economic costs of potato.

\section{MATERIALS AND METHODS}

Two field experiments were conducted in the Baramoon Research Station, Mansoura, Dakahlia Governorate, Egypt $\left(+7 \mathrm{~m}\right.$ altitude, $30^{\circ} 11^{-}$ latitude and $28^{\circ} 26^{-}$longitude), during Nili seasons of 2007/08 and 2008/09, to study the effect of slow release-N (urea formaldehyde "UF", Sulfur coated urea "SCU" and compost) and soluble-N (ammonium nitrate "AN") fertilizer on productivity, and quality of potato cv. Cara. Seed tubers were planted on $15^{\text {th }}$ of October in both seasons of study. Plot area was $11.25 \mathrm{~m}^{2}$; consisted of 3 ridges; $5 \mathrm{~m}$ long; $75 \mathrm{~cm}$ wide, and $25 \mathrm{~cm}$ apart.

Some physical and chemical properties of the experimental soil at the depth of $0-30 \mathrm{~cm}$ were determined according to the standard procedures as described by Page (1982) (Table 1). The chemical analysis of the used compost was determined using standard methods described by AOAC (1990) (Table 2).

Table 1: Some physical and chemical properties of the experimental soil.

\begin{tabular}{|c|c|c|c|c|c|}
\hline \multirow{2}{*}{$\begin{array}{l}\text { Some Physical } \\
\text { properties }\end{array}$} & \multicolumn{2}{|c|}{ Values } & \multirow{2}{*}{$\begin{array}{c}\text { Some Chemical } \\
\text { Properties }\end{array}$} & \multicolumn{2}{|c|}{ Values } \\
\hline & $1^{\text {st }}$ season & $2^{\text {nd }}$ season & & $1^{\text {st }}$ season & $2^{\text {nd }}$ season \\
\hline Sand (\%) & 27.8 & 28.0 & $\mathrm{pH}$ value & 8.1 & 7.9 \\
\hline Silt (\%) & 31.6 & 31.9 & $\mathrm{EC} \mathrm{dSm}{ }^{-1}$ & 0.9 & 0.8 \\
\hline Clay (\%) & 40.6 & 40.1 & Total N (\%) & 0.03 & 0.04 \\
\hline Texture class & Clay-loam & Clay-loam & $\begin{array}{c}\text { Available } \mathrm{N}(\mathrm{ppm}) \\
\mathrm{NH}_{4}-\mathrm{N} \\
\mathrm{NO}_{2}-\mathrm{N} \\
\mathrm{NO}_{3}-\mathrm{N}\end{array}$ & $\begin{array}{l}23.37 \\
0.162 \\
13.21\end{array}$ & $\begin{array}{l}23.00 \\
0.126 \\
13.12\end{array}$ \\
\hline $\mathrm{CaCO}_{3}(\%)$ & 3.1 & 3.2 & Available P (ppm) & 12.3 & 12.1 \\
\hline Organic matter (\%) & 1.4 & 1.6 & Available K (ppm) & 304 & 295 \\
\hline
\end{tabular}

A complete randomized blocks design with three replicates was used. The experiment included 14 treatments, which were as follows:

1. Ammonium nitrate, AN $(33.5 \% \mathrm{~N})$; recommended full dose (RD) of $\mathrm{N}$ at the rate of $180 \mathrm{~kg} \mathrm{~N} \mathrm{fed}^{-1}$ (Control).

2. Compost, $(1.2 \% \mathrm{~N})$; at the rate of $\mathbf{1 8}$ ton fed $^{-1}$; as fresh weight (moisture $=21.7 \%)$.

3. Urea formaldehyde, UF1 $(36.2 \% \mathrm{~N})$; at the rate of $135 \mathrm{~kg} \mathrm{~N} \mathrm{fed}^{-1}$.

4. Urea formaldehyde, UF2 $(36.2 \% \mathrm{~N})$; at the rate of $90 \mathrm{~kg} \mathrm{~N} \mathrm{fed}^{-1}$.

5. Sulfur coated urea, SCU1 $(32.0 \% \mathrm{~N})$; at the rate of $135 \mathrm{~kg} \mathrm{~N}^{-1} \mathrm{fed}^{-1}$.

6. Sulfur coated urea, SCU2 $(32.0 \% \mathrm{~N})$; at the rate of $90 \mathrm{~kg} \mathrm{~N} \mathrm{fed}^{-1}$.

7. AN $\left(90 \mathrm{~kg} \mathrm{~N} \mathrm{fed}^{-1}\right)+$ UF3 $\left(67.5 \mathrm{~kg} \mathrm{~N} \mathrm{fed}^{-1}\right)$.

8. AN $\left(90 \mathrm{~kg} \mathrm{~N} \mathrm{fed}^{-1}\right)+$ UF4 $\left(45 \mathrm{~kg} \mathrm{~N} \mathrm{fed}^{-1}\right)$.

9. AN $\left(90 \mathrm{~kg} \mathrm{~N} \mathrm{fed}^{-1}\right)+$ SCU3 $\left(67.5 \mathrm{~kg} \mathrm{~N} \mathrm{fed}^{-1}\right)$.

10. AN $\left(90 \mathrm{~kg} \mathrm{~N} \mathrm{fed}^{-1}\right)+$ SCU4 $\left(45 \mathrm{~kg} \mathrm{~N} \mathrm{fed}^{-1}\right)$.

11. Compost $\left(9\right.$ ton fed. $\left.{ }^{-1}\right)+$ UF3 $\left(67.5 \mathrm{~kg} \mathrm{~N} \mathrm{fed}^{-1}\right)$. 
Ezzat, A. S. et al.

12. Compost $\left(9\right.$ ton fed $\left.{ }^{-1}\right)+$ UF4 $\left(45 \mathrm{~kg} \mathrm{~N} \mathrm{fed}^{-1}\right)$.

13. Compost $\left(9\right.$ ton fed. $\left.{ }^{-1}\right)+\operatorname{SCU} 3\left(67.5 \mathrm{~kg} \mathrm{~N}^{-1} \mathrm{fed}^{-1}\right)$.

14. Compost $\left(9\right.$ ton fed. $\left.{ }^{-1}\right)+$ SCU4 $\left(45 \mathrm{~kg} \mathrm{~N}\right.$ fed $\left.^{-1}\right)$.

Ammonium nitrate was used as a soluble $\mathrm{N}$-fertilizer, while, compost, UF and SCU were used as a slow release $\mathrm{N}$-fertilizers.

Table 2 : Some properties of compost used in experiments during 2007/08 and 2008/09 seasons.

\begin{tabular}{|c|c|c|c|c|c|}
\hline \multirow{2}{*}{ Properties } & \multicolumn{2}{|c|}{\begin{tabular}{|l|} 
Values \\
\end{tabular}} & \multirow{2}{*}{ Properties } & \multicolumn{2}{|c|}{ Values } \\
\hline & $\mathbf{1}^{\text {st }}$ season & $2^{\text {nd }}$ season & & $1^{\text {st }}$ season & $2^{\text {nd }}$ season \\
\hline $\mathrm{N}(\%)$ & 1.20 & 1.19 & $\mathrm{pH}$ & 6.80 & 6.75 \\
\hline $\mathrm{P}(\%)$ & 0.41 & 0.39 & E.C. $\left(\mathrm{dSm}^{-1}\right)$ & 0.85 & 1.20 \\
\hline $\mathrm{K}(\%)$ & 1.67 & 1.70 & Fe (ppm) & 1822 & 1685 \\
\hline Organic carbon (\%) & 16.90 & 16.80 & $\mathrm{Mn}(\mathrm{ppm})$ & 274 & 286 \\
\hline $\mathrm{C} / \mathrm{N}$ ratio & 14.08 & 14.12 & $\mathrm{Zn}(\mathrm{ppm})$ & 190 & 210 \\
\hline
\end{tabular}

The slow release-N (urea formaldehyde UF 1 \& 2; Sulfur coated urea SCU $1 \& 2$, and compost) at the previously mentioned rates were added to experimental soil before planting. Ammonium nitrate (soluble form) was added at three equal doses, i. e. the first after emergence, and second and third doses were applied with $2^{\text {nd }}$ and $3^{\text {rd }}$ irrigation, respectively. Single superphosphate $\left(15.5 \% \quad \mathrm{P}_{2} \mathrm{O}_{5}\right)$ was applied with slow release $\mathrm{N}$-fertilizers (before planting) at the rate of $75 \mathrm{~kg} \mathrm{P}_{2} \mathrm{O}_{5} \mathrm{fed}^{-1}$. Potassium sulphate $(48 \%$ $\mathrm{K}_{2} \mathrm{O}$ ) was used as a source of potassium at the rate of $96 \mathrm{~kg} \mathrm{~K}_{2} \mathrm{O}$ fed ${ }^{-1}$ and was added in two equal doses with the $2^{\text {nd }}$ and $3^{\text {rd }}$ doses of ammonium nitrate (soluble form). Other agricultural practices were conducted according to recommendations. At 70 days after planting (DAP), a random sample of five plants was taken from each experimental unit to determine the growth parameters of potato plants (plant height, leaf area and dry weight/plant). At the harvesting time (130 DAP), the tuber yield fed ${ }^{-1}$ and yield grading plot ${ }^{1}$ were recorded. A representative sample of 10 to 15 healthy tubers from each experimental plot was selected from the largest sizes to obtain quality data (dry matter, specific gravity, starch, and nitrate and nitrite content) according to the methods described by (AOAC, 1990). Nitrogen, phosphorus and potassium concentrations in plant leaves were determined at 50, 70 and 90 DAP using the methods described by Cottenie et al., (1982). The soil samples were taken out from plots for $\mathrm{N}, \mathrm{P}$ and $\mathrm{K}$ determination at 60,90 and 120 DAP according to Black (1965). N, P and K concentrations in the digested dry weight of tubers were determined according to the methods described by Olsen and Sommers (1982). For calculation of nitrogen use efficiency (NUE), total tuber yield $\left(\mathrm{kg} \mathrm{fed}^{-1}\right)$ was divided by the amount of nitrogen in $\mathrm{kg} \mathrm{fed}^{-1}$ (Aujla et al., 1982). Economic evaluation, based on yield as an average of two seasons was estimated. Data obtained were subjected to statistical analysis by the technique of analysis of variance (ANOVA) according to Snedecor and Cochran (1982). The treatments mean were compared using the last significant differences (LSD) at $5 \%$ level of probability as described by Steel and Torrie (1980). 


\section{RESULTS AND DISCUSSION}

\section{Vegetative growth parameters:}

Data presented in Table 3 demonstrate the effect of various treatments of slow release- $\mathrm{N}$ and soluble- $\mathrm{N}$ fertilizers on vegetative growth parameters of potato plants expressed as plant height, leaf area/plant and dry weight/plant. Significant effects on vegetative growth characters was obtained under the treatment where Compost 9 ton fed plus SCU3 $67.5 \mathrm{~kg} \mathrm{~N}^{-1}{ }^{-1}$ was applied in comparison with other treatments, in both seasons of study.

Table 3: Vegetative growth characters of potato as affected by slow and soluble $\mathrm{N}$-fertilizers in $2007 / 08$ and $2008 / 09$ seasons.

\begin{tabular}{|c|c|c|c|c|c|c|}
\hline \multirow[t]{2}{*}{ Characters } & \multicolumn{2}{|c|}{$\begin{array}{l}\text { Plant height } \\
\text { (cm) }\end{array}$} & \multicolumn{2}{|c|}{$\begin{array}{c}\text { Leaf } \\
\text { area/plant } \\
\left(\mathrm{cm}^{2}\right)\end{array}$} & \multicolumn{2}{|c|}{$\begin{array}{c}\text { Dry } \\
\text { weight/plant } \\
\text { (g) }\end{array}$} \\
\hline & $\begin{array}{l}2007 / \\
2008\end{array}$ & $\begin{array}{l}2008 / \\
2009\end{array}$ & $\begin{array}{l}2007 / \\
2008 \\
\end{array}$ & $\begin{array}{l}2008 / \\
2009 \\
\end{array}$ & $\begin{array}{l}2007 / \\
2008 \\
\end{array}$ & $\begin{array}{c}2008 / \\
2009 \\
\end{array}$ \\
\hline $\begin{array}{l}\left.\text { 1- Ammonium nitrate (AN) (180 kg N fed. } .^{-1}\right) \text {, } \\
\text { Control }\end{array}$ & 54.67 & 55.00 & 4288 & 4212 & 28.95 & 29.15 \\
\hline 2- Compost (18 ton fed..$\left.^{-1}\right)$ & 56.00 & 57.00 & 4633 & 4835 & 31.27 & 32.73 \\
\hline 3- Urea formaldehyde (UF1); $135 \mathrm{~kg} \mathrm{~N}$ fed. $^{-1}$ & 57.33 & & 4521 & 4712 & 30.52 & 27.30 \\
\hline 4- Urea formaldehyde (UF2); 90 kg N fed. ${ }^{-1}$ & 52.00 & 52.33 & 4229 & 3918 & 28.55 & 27.16 \\
\hline 5-Sulfur coated urea (SCU1); 135 kg N fed. ${ }^{-1}$ & 58.67 & 56.33 & 5054 & 5118 & 34.12 & 33.76 \\
\hline 6-Sulfur coated urea (SCU2); 90 kg N fed. ${ }^{-1}$ & 52.33 & 54.67 & 4210 & 4280 & 28.42 & 26.70 \\
\hline 7- AN $90 \mathrm{~kg} \mathrm{~N}+$ UF3 $67.5 \mathrm{~kg} \mathrm{~N}_{\text {fed. }}^{-1}$ & 49.67 & 44.67 & 3197 & 3120 & 21.58 & 22.20 \\
\hline 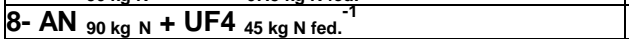 & 49.33 & 43.33 & 3723 & 3681 & 25.13 & 25.76 \\
\hline+ SCU3 67.5 & 47.33 & 42.67 & 3976 & 3824 & 26.84 & 24.34 \\
\hline 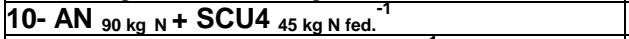 & 43.00 & 40.00 & 3582 & 3426 & 24.18 & 23.42 \\
\hline 11-Compost 9 ton + UF3 $67.5 \mathrm{~kg} \mathrm{~N}$ fed. $^{-1}$ & 54.66 & 54.00 & 4323 & 4180 & 29.18 & 28.70 \\
\hline 12-Compost 9 ton + UF4 $45 \mathrm{~kg} \mathrm{~N}_{\text {fed. }}{ }^{-1}$ & 50.33 & 48.33 & 4906 & 4980 & 33.12 & 32.00 \\
\hline 13-Compost 9 ton + SCU3 $67.5 \mathrm{~kg} \mathrm{~N}_{\text {fed. }}{ }^{-1}$ & 60.67 & 58.00 & 5446 & 5423 & 36.76 & 34.84 \\
\hline 14-Compost 9 ton + SCU4 $45 \mathrm{~kg} \mathrm{~N}_{\text {fed. }}^{-1}$ & 47.00 & 46.00 & 4130 & 4286 & 27.88 & 26.00 \\
\hline LSD at 0.05 level & 2.19 & 3.52 & 267.11 & 328.14 & 2.17 & 2.26 \\
\hline
\end{tabular}

The best results obtaining from using SCU can be attributed to the slow release of nitrogen to meet potato plants requirement, where the coat of urea with sulfur can low the dissolution rate of urea than AN (soluble form), so reduce $\mathrm{N}$ loss from soil, gradually hydrolyzed in parallel with the plant demand, gives a chance for more nitrogen uptake by plant roots and gradual improvement in $\mathrm{N}$-supply power for improving $\mathrm{N}$ efficiency of slow release as compared with soluble form (Waddell et al., 1999; Allen, 1984 and Zvomuya et al., 2003). Also, the increases occurred in plant vegetative growth may be due to that SCU contain nitrogen and sulfur elements, and both elements are presented in the molecule of most amino acids and protein, in addition to the role of both elements in several biochemical processes that related to plant growth (Marschner, 1995). Sulfur may also decrease the soil pH, so resulting in increasing the available form of most nutrients, especially micro-elements. Besides, the beneficial effect of compost on vegetative growth may be related to improve physical conditions of the soil, provide energy for microorganism activity, increased nutrient supply and improve the efficiency of macro and micronutrients (Ezzat, 2001, and Mallory and Porter, 2007). 


\section{Yield and yield components:}

The effect of various sources of slow release- $\mathrm{N}$ and soluble- $\mathrm{N}$ fertilizers on total tuber yield of potato and its different components are shown in Table 4. The results indicate that total tuber yield differed significantly with the different fertilizer management, in both seasons. Highest tuber yield (14.492 and 13.640 ton $^{\text {fed }}{ }^{-1}$, in both seasons, respectively) was obtained under the treatment received Compost 9 ton fed ${ }^{-1}+\mathrm{SCU} 367.5 \mathrm{~kg} \mathrm{~N}^{-1}{ }^{-1}$. The second treatment regarding the increase in tuber yield was SCU1 (135 kg N fed ${ }^{-1}$ ) without significant differences between $1^{\text {st }}$ and $2^{\text {nd }}$ treatments, respectively. The percentage increases over the control AN (soluble form) reached to $11.68,11.73 \%$ and $9.35,8.79 \%$ for both superiority treatments, in both seasons, respectively. On the other hand, the lowest tuber yield (9.150 and 7.520 ton fed $^{-1}$ ) was recorded under the treatment of AN $90 \mathrm{~kg} \mathrm{Ned}^{-1}+\mathrm{UF}_{45} \mathrm{~kg}$ $\mathrm{N}$ fed. ${ }^{-1}$, in both seasons. Higher tuber yields for compost treatments were possibly due to extra $\mathrm{N}$ and other nutrients present in compost but not in other N sources (Waddell et al., 1999; Ezzat, 2001 and Mallory and Porter, 2007). Nyiraneza and Snapp (2007) reported that potato tuber yield and $\mathrm{N}$ uptake in the integrated treatments of the organic fertilizer were 14 to $33 \%$ higher than the inorganic fertilizer. On the other hand, the use of SCU may regulate $\mathrm{N}$-nutrient release to be used more efficiently by plants, subsequently reducing- $\mathrm{N}$ leaching losses and providing a constant supply of nutrients to the roots according to growing pattern of potato plants (Lorenz et al., 1974; Liegel and Walsh, 1976; Waddell et al., 1999 and Pack, 2004).

Table 4: Total tuber yield and yield components of potato as affected by slow and soluble $\mathrm{N}$-fertilizers in $2007 / 08$ and $2008 / 09$ seasons.

\begin{tabular}{|c|c|c|c|c|c|c|c|c|}
\hline \multirow[b]{3}{*}{ Treatments } & \multirow{2}{*}{\multicolumn{2}{|c|}{$\begin{array}{c}\text { Total tuber } \\
\text { yield } \\
\text { (Ton fed. }^{-1} \text { ) }\end{array}$}} & \multicolumn{6}{|c|}{ Tuber grading (Ton fed..$^{-1}$ ) } \\
\hline & & & \multicolumn{2}{|c|}{$\begin{array}{l}\text { Tuber weight } \\
>60 \mathrm{~mm}\end{array}$} & \multicolumn{2}{|c|}{$\begin{array}{l}\text { Tuber weight } \\
30: 60 \mathrm{~mm}\end{array}$} & \multicolumn{2}{|c|}{$\begin{array}{l}\text { Tuber weight } \\
<30 \mathrm{~mm}\end{array}$} \\
\hline & $\begin{array}{c}2007 / \\
2008\end{array}$ & $\begin{array}{l}2008 / \\
2009\end{array}$ & $\begin{array}{l}2007 / \\
2008\end{array}$ & $\begin{array}{l}2008 / \\
2009\end{array}$ & $\begin{array}{l}2007 / \\
2008\end{array}$ & $\begin{array}{l}2008 / \\
2009\end{array}$ & $\begin{array}{l}2007 / \\
2008\end{array}$ & $\begin{array}{l}2008 / \\
2009\end{array}$ \\
\hline $\begin{array}{l}\text { 1-Ammonium nitrate } \\
\text { (AN) }\left(180 \mathrm{~kg} \mathrm{~N} \text { fed. } .^{-1}\right) \text {, Control }\end{array}$ & 12.800 & 12.040 & 5.600 & 5.280 & 6.540 & 6.180 & 0.660 & 0.580 \\
\hline 2- Compost (18 ton fed..$^{-1}$ ) & 13.410 & 12.920 & 5.900 & 5.840 & 6.908 & 6.580 & 0.602 & 0.500 \\
\hline $\begin{array}{l}\text { 3- Urea formaldehyde } \\
\text { (UF1); } 135 \mathrm{~kg} \mathrm{~N}^{-1} \text { fed. }^{-1}\end{array}$ & 12.920 & 13.400 & 5.600 & 6.120 & 6.780 & 6.760 & 0.540 & 0.520 \\
\hline $\begin{array}{l}\text { 4- Urea formaldehyde } \\
\text { (UF2); } 90 \mathrm{~kg} \mathrm{~N} \text { fed. }{ }^{-1}\end{array}$ & 11.300 & 10.800 & 4.600 & 5.120 & 5.740 & 4.880 & 0.960 & 0.800 \\
\hline $\begin{array}{l}\text { 5-Sulfur coated urea } \\
\text { (SCU1); } 135 \mathrm{~kg} \mathrm{~N}_{\text {fed. }}{ }^{-1}\end{array}$ & 14.120 & 13.200 & 6.040 & 5.920 & 7.576 & 6.800 & 0.592 & 0.480 \\
\hline $\begin{array}{l}\text { 6-Sulfur coated urea } \\
\text { (SCU2); } 90 \text { kg N fed. }{ }^{-1}\end{array}$ & 11.712 & 11.160 & 4.792 & 5.200 & 6.000 & 5.100 & 0.920 & 0.860 \\
\hline 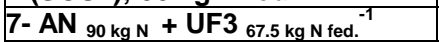 & 9.800 & 9.000 & 3.860 & 4.240 & 5.000 & 3.820 & 0.940 & 0.940 \\
\hline 8- $\mathrm{AN}{ }_{90 \mathrm{~kg} \mathrm{~N}}+\mathrm{UF}_{45} \mathrm{~kg} \mathrm{~N}_{\text {fed. }}^{-1}$ & 9.150 & 7.520 & 3.670 & 3.340 & 4.300 & 3.200 & 1.180 & 0.980 \\
\hline 9- $\mathrm{AN}_{90 \mathrm{~kg} \mathrm{~N}}+\mathrm{SCU3}_{67.5 \mathrm{~N} \mathrm{~kg} \mathrm{fed}^{-1}}$ & 9.693 & 9.040 & 2.972 & 3.400 & 5.600 & 4.780 & 1.120 & 0.860 \\
\hline 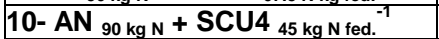 & 9.412 & 8.120 & 4.320 & 3.800 & 4.500 & 3.400 & 0.592 & 0.920 \\
\hline 11-Compost 9 ton + UF3 $67.5 \mathrm{~kg} \mathrm{~N}_{\text {fed. }}^{-1}$ & 12.100 & 11.920 & 4.988 & 5.200 & 6.320 & 6.100 & 0.792 & 0.620 \\
\hline 12-Compost 9 ton + UF4 $45 \mathrm{~kg} \mathrm{~N}_{\text {fed. }}^{-1}$ & 10.916 & 9.720 & 4.360 & 4.960 & 5.556 & 4.080 & 1.000 & 0.680 \\
\hline $\begin{array}{c}\text { 13-Compost } 9 \text { ton+SCU3 } 67.5 \mathrm{~kg} \mathrm{~N} \\
\text { fed. }\end{array}$ & 14.492 & 13.640 & 6.340 & 6.480 & 7.692 & 6.760 & 0.460 & 0.400 \\
\hline $\begin{array}{c}\text { 14-Compost } 9 \text { ton }+ \text { SCU4 } 45 \mathrm{~kg} \mathrm{~N} \\
\text { fed. }\end{array}$ & 10.568 & 10.240 & 4.408 & 4.640 & 5.100 & 4.920 & 1.060 & 0.680 \\
\hline LSD at 0.05 level & 0.643 & 0.717 & 0.638 & 0.983 & 1.110 & 1.020 & 0.101 & 0.166 \\
\hline
\end{tabular}


In this respect, Worthington et al. (2007) found that potato plants in controlled release fertilizer (CRF) treatments produced significantly higher marketable tuber yields in both years compared with plants in AN fertilizer treatments.

Regarding, the tuber grade-out and size grades (over 60 and 30: 60 $\mathrm{mm}$ ) Table 4, it is obvious that it took the manner of total tuber yield as previously mentioned. Science, total yield increases were due to primarily the increase in tuber size in larger and medium grades and decrease of the small grades. In this respect, the treatment of Compost 9 ton fed $^{-1}+$ SCU3 $67.5 \mathrm{~kg} \mathrm{~N}^{-1}$ increased significantly weights of large $(>60 \mathrm{~mm})$ and medium tubers (30: 60 $\mathrm{mm})$ and decreased significantly small tuber weight $(<30 \mathrm{~mm})$, in both seasons, respectively.

Similar observations were reported by Waddell et al. (1999), Tartoura et al. (2003) and Pack (2004); they associated the increase in tuber yield from slow release- $\mathrm{N}$ fertilizers with an increase in the number of tubers in the medium and large grades (marketable tubers) due to the increase in weight of tubers.

\section{Tuber quality:}

Data presented in Table 5 show that, there were significant differences in tuber quality parameters, and nitrate as well as nitrite content in potato tuber, in both seasons. Application of Compost 9 ton fed $^{-1}+$ SCU3 $67.5 \mathrm{~kg} \mathrm{~N}^{-1}{ }^{-1}$ significantly increased tuber dry matter (in both season), starch and specific gravity of tuber ( $1^{\text {st }}$ season, only) and significantly decreased nitrate and nitrite content of tuber (both season), in comparison with other treatments.

It could be attributed that the compost and/or SCU fertilizers maintain the nutrients supply to the plants during growth period more than AN and its combinations. These increases in dry matter, starch and specific gravity may be attributed to the effect of organic and SCU fertilizers on increasing the availability of certain elements and their supply to plant (Table 6). These results were confirmed with those of Waddell et al. (1999) and Pack (2004).

Regarding, nitrate and nitrite content in tuber, the steady release of the nitrogen from compost + SCU may have resulted that nitrogen has been taken up mainly in the form of ammonium which probably caused low nitrate content of the tuber (Kolbe et al., 1995). These results are similar to that reported by Govind et al. (1976) who showed that the effect of SCU on nitrate accumulation was minimal in cabbage and tomato.

\section{NPK (tubers, 130 DAP) and NUE:}

A significant differences between treatments occurred for tuber $\mathrm{N}, \mathrm{P}$ and $\mathrm{K}$ concentration (Table 6). Among various treatments, the Compost 9 ton fed $^{-1}+$ SCU3 $67.5 \mathrm{~kg} \mathrm{~N}^{-1}{ }^{-1}$ had the highest NPK \%.

Also, data in Table 6 illustrate that the N, P and $\mathrm{K} \%$ under compost and/or slow release treatments generally were increased significantly compared to AN (soluble form) in both seasons.

This may be attributed to the increase in growth characteristics (Table3) of the plant and linked this to nitrogen accumulation patterns (i.e., little $\mathrm{N}$ demand in very early, to heavy $\mathrm{N}$ demand during vegetative growth and bulking stages, to little $\mathrm{N}$ demand during maturation and senescence (Pack, 2004; Fig 1) which allow to increase $\mathrm{P}$ and $\mathrm{K}$ concentrations 
Ezzat, A. S. et al.

5 
Table 6: Mineral content of potato tuber and NUE as affected by slow and soluble $\mathrm{N}$-fertilizers in $2007 / 08$ and $2008 / 09$ seasons.

\begin{tabular}{|c|c|c|c|c|c|c|c|c|}
\hline \multirow[b]{2}{*}{ Treatments } & \multicolumn{2}{|c|}{$\begin{array}{c}\mathbf{N} \\
(\%)\end{array}$} & \multicolumn{2}{|c|}{$\begin{array}{c}\mathbf{P} \\
(\%)\end{array}$} & \multicolumn{2}{|c|}{$\begin{array}{c}\mathbf{K} \\
(\%)\end{array}$} & \multicolumn{2}{|c|}{$\begin{array}{l}\text { NUE Kg tuber } \\
\text { per } \mathbf{k g ~ N}\end{array}$} \\
\hline & $\begin{array}{l}2007 / \\
2008\end{array}$ & $\begin{array}{l}2008 / \\
2009 \\
\end{array}$ & $\begin{array}{l}2007 / \\
2008 \\
\end{array}$ & $\begin{array}{c}2008 / \\
2009 \\
\end{array}$ & $\begin{array}{l}2007 / \\
2008\end{array}$ & $\begin{array}{l}2008 / \\
2009 \\
\end{array}$ & $\begin{array}{l}2007 / \\
2008\end{array}$ & $\begin{array}{l}2008 / \\
2009 \\
\end{array}$ \\
\hline $\begin{array}{l}\text { 1- Ammonium nitrate } \\
\text { (AN) }\left(180 \mathrm{~kg} \mathrm{~N} \mathrm{fed}^{-1} \text {.), Control }\right.\end{array}$ & 1.43 & 1.48 & 0.26 & 0.28 & 3.66 & 3.52 & 71.11 & 66.89 \\
\hline 2- Compost (18 ton fed. $\left.{ }^{-1}\right)$ & 1.68 & 1.62 & 0.30 & 0.32 & 3.78 & 3.78 & 74.50 & 71.78 \\
\hline $\begin{array}{l}\text { 3- Urea formaldehyde } \\
\text { (UF1); } 135 \mathrm{~kg} \mathrm{~N}^{-1} \text { fed. }^{-1}\end{array}$ & 1.55 & 1.50 & 0.29 & 0.31 & 3.70 & 3.60 & 95.70 & 99.25 \\
\hline $\begin{array}{l}\text { 4- Urea formaldehyde } \\
\text { (UF2); } 90 \mathrm{~kg} \mathrm{~N} \text { fed. }{ }^{-1}\end{array}$ & 1.51 & 1.51 & 0.21 & 0.24 & 3.56 & 3.52 & 125.56 & 120.00 \\
\hline $\begin{array}{l}\text { 5-Sulfur coated urea } \\
{\text { (SCU1); } 135 \mathrm{~kg} \mathrm{~N}^{-1}}^{-1}\end{array}$ & 1.68 & 1.60 & 0.32 & 0.34 & 3.87 & 3.63 & 104.59 & 97.78 \\
\hline $\begin{array}{l}\text { 6-Sulfur coated urea } \\
\text { (SCU2); } 90 \mathrm{~kg} \mathrm{~N}^{-1} \text { fed. }^{-1}\end{array}$ & 1.74 & 1.64 & 0.22 & 0.26 & 3.60 & 3.50 & 130.13 & 124.00 \\
\hline 7- AN $90 \mathrm{~kg}+\mathrm{UF} 67.5 \mathrm{~kg} \mathrm{~N}^{-1}{ }^{-1}$ & 1.27 & 1.25 & 0.19 & 0.19 & 3.51 & 3.10 & 62.22 & 57.14 \\
\hline 8- AN $90 \mathrm{~kg}+\mathrm{UF} 445 \mathrm{~kg} \mathrm{~N}_{\text {fed. }}^{-1}$ & 1.23 & 1.22 & 0.18 & 0.17 & 3.36 & 3.28 & 69.72 & 60.15 \\
\hline 9- AN $90 \mathrm{~kg}+\mathrm{SCU}_{67.5 \mathrm{~kg} \mathrm{~N} \text { fed. }^{-1}}$ & 1.25 & 1.24 & 0.19 & 0.19 & 3.32 & 3.21 & 61.54 & 57.40 \\
\hline 10- AN $90 \mathrm{~kg}+\mathrm{SCU}_{45} \mathrm{~kg} \mathrm{~N}_{\mathrm{fed}^{-1}}{ }^{-1}$ & 1.21 & 1.22 & 0.18 & 0.17 & 3.26 & 3.26 & 67.78 & 55.70 \\
\hline 11-Compost 9 ton + UF3 $67.5 \mathrm{~kg} \mathrm{~N}_{\text {fed. }}$ & 1.51 & 1.50 & 0.24 & 0.26 & 3.64 & 3.51 & 76.82 & 75.68 \\
\hline 12-Compost 9 ton + UF4 $45 \mathrm{~kg} \mathrm{~N}$ fed. $^{-1}$ & 1.43 & 1.38 & 0.20 & 0.21 & 3.54 & 3.50 & 80.86 & 72.00 \\
\hline $\begin{array}{c}\text { 13-Compost } 9 \text { ton + SCU3 } 67.5 \mathrm{~kg} \mathrm{~N} \\
\text { fed. }\end{array}$ & 1.78 & 1.70 & 0.34 & 0.36 & 3.90 & 3.88 & 92.01 & 86.60 \\
\hline 14-Compost 9 ton + SCU4 $45 \mathrm{~kg} \mathrm{~N}$ fed. & 1.50 & 1.56 & 0.20 & 0.21 & 3.61 & 3.60 & 78.28 & 75.85 \\
\hline LSD at 0.05 level & 0.03 & 0.05 & 0.02 & 0.06 & 0.02 & 0.05 & --- & ---- \\
\hline
\end{tabular}

As regard to, nitrogen use efficiency (NUE), data presented in Table 6 indicate that the values of NUE ranged form 55.70 to 130.13. The greatest value of NUE was obtained by the application of SCU2 followed by UF2. Pack (2004) found that all controlled release fertilizers $\left(\mathrm{CRF}_{\mathrm{s}}\right)$ can improve $\mathrm{N}$ use efficiency. AN and its combinations with slow release fertilizers (UF or SCU) gave the lowest value, in this respect, and the obtained results may be due to that AN depressed the dry matter content (Table 5). On the other hand, the highest values of NUE were associated with dry weigh of plant (Table 3), higher values of nitrogen concentration (Table 6) and increasing non-nitrogenous compounds as indicated by Sullivan et al. (1974)

\section{NPK (plant; 50, 70, and 90 DAP).}

Figurers 1,2 and 3 illustrate that the highest values of NK were at 70 DAP in potato plants, followed by 50 DAP and finally, 90 DAP, while $P$ attained the highest values in early stage (50 DAP).

Also, the highest values of NPK (\%) were obtained from potatoes receiving Compost 9 ton fed ${ }^{-1}+$ SCU $367.5 \mathrm{~kg} \mathrm{~N}^{-1}{ }^{-1}$. These results are confirmed with those of Pack (2004) who found that potato plants need little $\mathrm{N}$ demand in early stage, moderate to heavy $\mathrm{N}$ demand during vegetative growth and bulking stage, and little $\mathrm{N}$ demand in maturation.

Also, these results can be discussed according to compost and SCU acts as a slow release of nitrogen and other nutrients and the beneficial effect of it appears in later growth stage (Kolbe et al., 1995). 
Ezzat, A. S. et al.

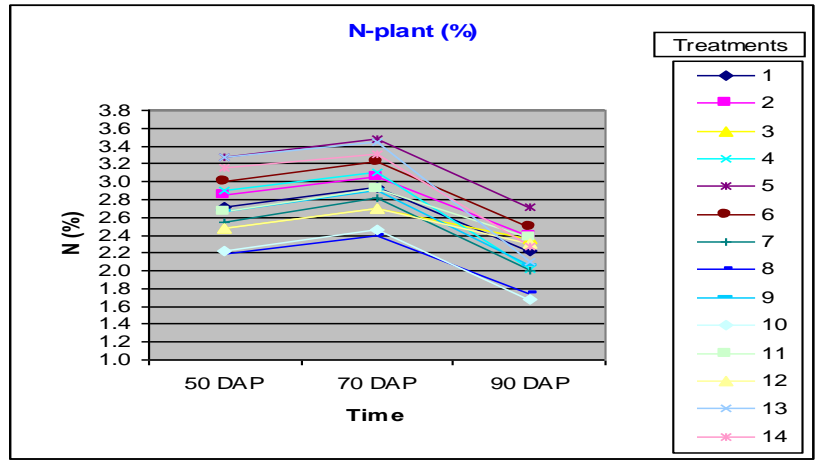

Fig 1: Nitrogen concentration in potato leaves at different stages as affected by slow- $\mathrm{N}$ and soluble- $\mathrm{N}$ fertilizers (average two seasons).

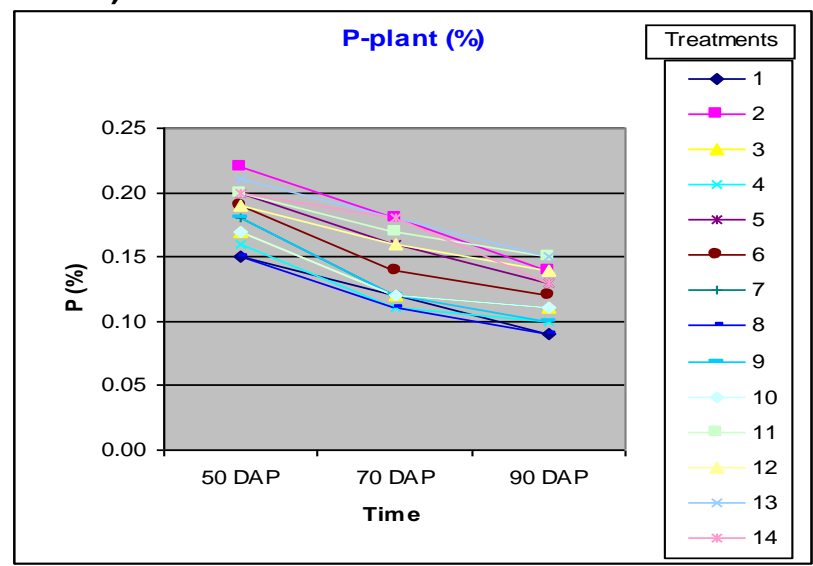

Fig 2: Phosphorus concentration in potato leaves at different stages as affected by slow-N and soluble- $\mathrm{N}$ fertilizers (average two seasons).

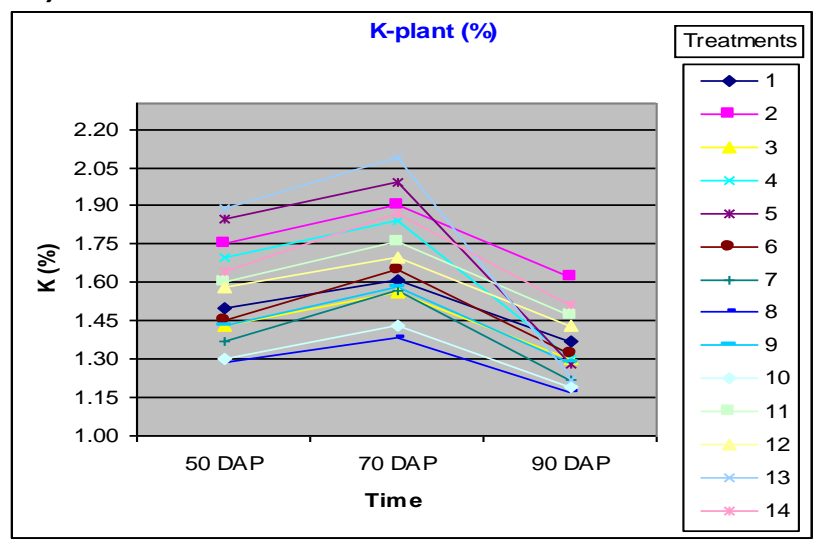

Fig 3: Potassium concentration in potato leaves at different stages as affected by slow-N and soluble-N fertilizers (average two seasons). 
6. NPK (soil; 60, 90, and 120 DAP).

Concerning, NPK in soil samples at different stages, Figures 4, 5, and 6 shows that, the highest NPK concentration were attained in the treatment of Compost 18 ton fed $^{-1}$ and all combinations of Compost plus SCU especially in later stage. Under the conditions of these treatments, the loss of NPK through leaching or volatilization is much minimized. Similar results were obtained by Matocha (1976). In this respect, Liegel and Walsh, (1976), in potato experiments, found that there was significantly more residual $\mathrm{N}$ in the soil for SCU treatments as compared to soluble form treatments. Also, it is noticed that the $1^{\text {st }}$ stage (60 DAP) gave the highest values of NPK and decreased with growing stages. This is may be due to efficiency of recovery by potato plants and use efficiency of slow release fertilizers.

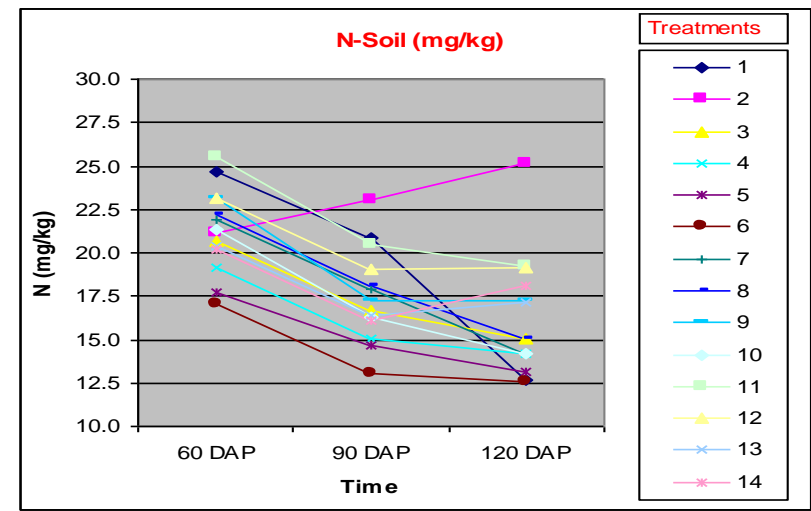

Fig 4: Nitrogen concentration in soil at different stages as affected by slow- $\mathrm{N}$ and soluble- $\mathrm{N}$ fertilizers (average two seasons).

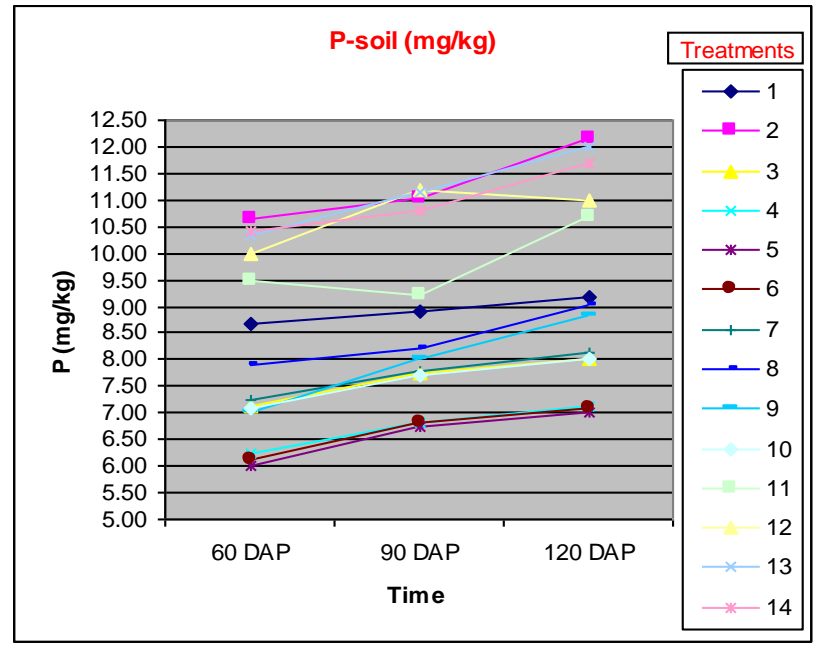

Fig 5: Phosphorus concentration in soil at different stages as affected by slow- $\mathrm{N}$ and soluble- $\mathrm{N}$ fertilizers (average two seasons). 
Ezzat, A. S. et al.

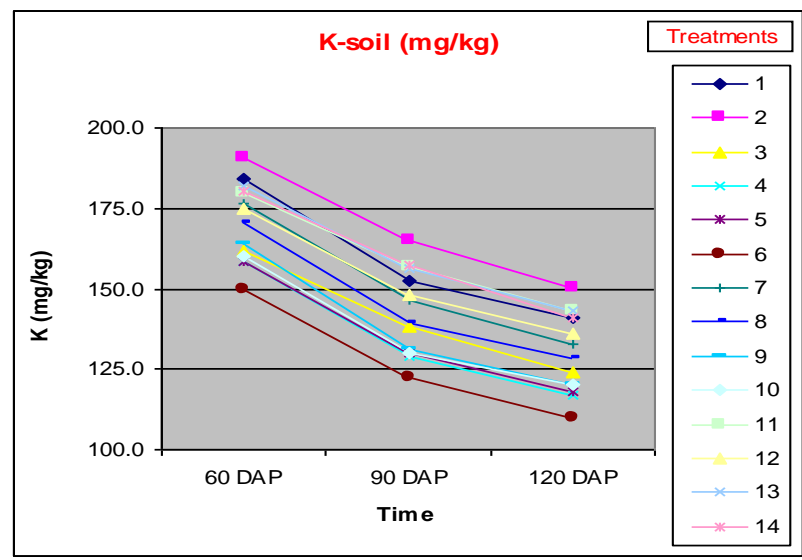

Fig 6: Potassium concentration in soil at different stages as affected by slow- $\mathrm{N}$ and soluble- $\mathrm{N}$ fertilizers (average two seasons).

\section{Economic evaluation:}

The data in Table 7 show that the highest net return ( $£ . € 10719 \mathrm{fed}^{-1}$ ) was obtained from potato receiving Compost 9 ton fed $^{-1}+$ SCU3 $67.5 \mathrm{~kg} \mathrm{~N}^{-1}{ }^{-1}$, in comparison with other treatments. Thus, this treatment proved to be economical for potato production. As a support for the present results, Hutchinson and Simonne (2003) indicated that one possibility for lowering the cost of planting would be the use of controlled-release fertilizers.

Table 7: Estimate of additional net return of treatments.

\begin{tabular}{|c|c|c|c|c|c|c|}
\hline Treatments & \begin{tabular}{|c|}
$\begin{array}{c}\text { Tuber } \\
\text { yield }^{\star} \\
\left(\text { Ton }^{*}\right. \\
\left.\text { fed }^{-1}\right)\end{array}$ \\
\end{tabular} & $\begin{array}{c}\text { Total } \\
\text { costs }^{\star \star} \\
(£ . € \\
\left.\text { fed }^{-1}\right) \\
\end{array}$ & $\begin{array}{c}\text { Additional } \\
\operatorname{cost}^{\star \star \star} \\
\left(£ . € \mathrm{fed}^{-1}\right)\end{array}$ & \begin{tabular}{|c|} 
Gross \\
return \\
$(£ . €$ \\
fed $\left.^{-1}\right)$ \\
\end{tabular} & \begin{tabular}{|c|} 
Net \\
return \\
$(£ . €$ \\
fed $\left.^{-1}\right)$
\end{tabular} & Order \\
\hline $\begin{array}{l}\text { 1- Ammonium nitrate (AN) }\left(180 \mathrm{~kg} \mathrm{~N}^{\text {Amd }}{ }^{-1} \text {.), }\right. \\
\text { Control }\end{array}$ & 12.420 & 5880 & 880 & 14904 & 9024 & 5 \\
\hline 2- Compost (18 ton fed ${ }^{-1}$.) & 13.165 & 5900 & 900 & 15798 & 9898 & 3 \\
\hline 3- Urea formaldehyde (UF1); $135 \mathrm{~kg} \mathrm{~N}$ fed. $^{-1}$ & 13.160 & 6491 & 1491 & 15792 & 9797 & 4 \\
\hline 4- Urea formaldehyde (UF2); $90 \mathrm{~kg} \mathrm{~N} \mathrm{fed}^{-1}$ & 11.050 & 5995 & 995 & 13260 & 6769 & 8 \\
\hline 5-Sulfur coated urea (SCU1); $135 \mathrm{~kg} \mathrm{~N}$ fed. $^{-1}$ & 13.660 & 6421 & 1421 & 16390 & 9969 & 2 \\
\hline 6-Sulfur coated urea (SCU2); 90 kg N fed. ${ }^{-1}$ & 11.436 & 5950 & 950 & 13723 & 7773 & 7 \\
\hline 7- AN $90 \mathrm{~kg}^{+} \mathrm{UF} 67.5 \mathrm{~kg} \mathrm{~N}_{\text {fed. }}^{-1}$ & 9.400 & 6185 & 1185 & 11280 & 5095 & 11 \\
\hline 8- AN $90 \mathrm{~kg}^{-}+\mathrm{UF}_{45} \mathrm{kgN} \mathrm{fed}^{-1}$ & 8.766 & 5937 & 937 & 10519 & 4582 & 13 \\
\hline 9- AN $90 \mathrm{~kg}+\mathrm{SCU}_{67.5 \mathrm{~kg} \mathrm{~N}_{\text {fed. }}^{-1}}$ & 9.367 & 6150 & 1150 & 11240 & 5090 & 12 \\
\hline 10- AN $90 \mathrm{~kg}+\mathrm{SCU} 4{ }_{45} \mathrm{~kg} \mathrm{~N}_{\text {fed. }}{ }^{-1}$ & 8.335 & 5915 & 915 & 10002 & 4087 & 14 \\
\hline 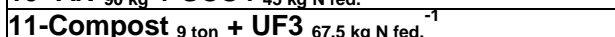 & 12.010 & 6195 & 1195 & 14412 & 8217 & 6 \\
\hline 12-Compost 9 ton $+\mathrm{UF}_{45} \mathrm{kq} \mathrm{N} \mathrm{fed}^{-1}$ & 10.318 & 5947 & 947 & 12381 & 6434 & 10 \\
\hline 13-Compost 9 ton + SCU3 $67.5 \mathrm{~kg} \mathrm{~N}$ ed. $^{-1}$ & 14.066 & 6160 & 1160 & 16879 & 10719 & 1 \\
\hline 14-Compost 9 ton + SCU4 $45 \mathrm{~kg} \mathrm{~N}$ fed. $^{-1}$ & 10.404 & 5925 & 925 & 12484 & 6559 & 9 \\
\hline
\end{tabular}




\section{Conclusion:}

Under the conditions of this study, this investigation suggest that, application of nitrogen fertilizers in the form of compost $\left(9\right.$ ton fed $\left.{ }^{-1}\right)+$ sulfur coated urea $\left(67.5 \mathrm{~kg} \mathrm{~N}^{-1} \mathrm{fed}^{-1}\right)$ in potato fields is indispensable to increase the vegetative characteristics, yield parameters and quality of tubers, in addition to lower concentrations in both nitrate and nitrite in tubers than the recommended rate of soluble form.

Moreover, the application of slow release fertilizers will save about $50 \%$ of the required amounts of $\mathrm{N}$-fertilizer, and will also reduce the pollution of environment. On the other side, the use of slow release fertilizers will reduce potato production cost especially in the developing countries like Egypt, and give the highest net profit for farmers.

\section{REFERENCES}

Allen, S. E. 1984. Slow-release nitrogen-fertilizers. In: Nitrogen in Crop Production, pp. 195-206. National Fertilizers Development Center South Sagoe Road, Madison, WI-53711, USA.

AOAC (Association of Official Analytical Chemists) .1990. Official Methods of Analysis. $15^{\text {th }}$ Ed., Washington, DC, USA.

Aujla, M. S., H. S. Thind, and G. S. Buttar. 2007. Fruit yield and water use efficiency of eggplant (Solanum melongema L.) as influenced by different quantities of nitrogen and water applied through drip and furrow irrigation. Scientia Horticultrae, 112: 142-148.

Black, C. A. 1965. Methods of Soil Analysis. Part 1 and 2. Amer. Soc. Agron. Inc., Madison, Wisconsin, USA.

Chatzoudis, G. K., and G. N. Valkanas. 1995. Monitoring the combined action of controlled release fertilizers and soil conditioner in soil. Comm. Soil. Sci. Plant. Anal., 26:2099.

Chien, S.H., L.I. Prochnow, and H. Cantarella. 2009. Recent developments of fertilizer production and use to improve nutrient efficiency and minimize environmental impacts. Advances in Agronomy, Vol. 102: 267-322.

Cottenie, A., M. Verloo, L. Kiekens, and G. Velghe. 1982. Biological and Analytical Aspects of Soil Pollution Hand Book. Gent, Belgium.

Ezzat, A. S. 2001. Effect of some organic and biofertilizers on growth, yield and quality of potato (Solanum tuberosum L.). Ph. D. Thesis. Fac. Agric., Mansoura Univ., 99 pp.

Fageria, N.K., and V.C. Baligar. 2005. Enhancing nitrogen use efficiency in crop plants. Advances in Agronomy, Vol. 88: 97-185.

Fox, R. H., W. P. Piekielek, and K. E. Macned. 1996. Estimating ammonia volatilization losses from urea fertilizers using a simplified micrometeorological sampler. Soil Sci. Soc. Am. J., 60: 596.

Govind, C. S., A. J. Patel, and D. A. Mays. 1976. Effect of sulfur-coated urea on yield, $\mathrm{N}$-uptake, and nitrate content in turnip greens, cabbage and tomato. J. Amer. Soc. Hort. Sci., 101(2):142-145. 
Hutchinson, C. M., and E. H. Simonne. 2003. Controlled-release fertilizer opportunities and costs for potato production in Florida. EDIS HS-941, http://edis.ifas.ufl.edu/HS187. 4 pp.

Kolbe, H., S. Meineke, and W. L. Zhany. 1995. Differences in organic and mineral fertilization on potato tubers yield and chemicals composition compared to model calculations. Agribiol. Res., 48 (10):63-73.

Liegel, E. A., and L. M. Walsh. 1976. Evaluation of sulfur-coated urea (SCU) applied to irrigated potatoes and corn. Agron. J., 68: 457-463.

Lorenz, O. A., B. L. Weir, and J. C. Bishop. 1974. Effect of sources of nitrogen on yield and nitrogen absorption of potatoes. Amer. Potato J., 51: 56-65.

Mallory, E. B. and G. A. Porter. 2007. Potato yield stability under contrasting soil management strategies. Agron. J., 99: 501-510.

Marschner, H. 1995. Mineral Nutrition of Higher Plants. $2^{\text {nd }}$ Ed. Academic Press, Harcourt Brace and Company, Publishers. London, New York, Tokyo, pp 864.

Matocha, J. E. 1976. Ammonia volatilization and nitrogen utilization from sulfur-coated urea and conventional nitrogen fertilizers. Soil Sci. Soc. Amer. J., 40 (4): 597-601.

Nyiraneza, J. and S. Snapp .2007. Integrated management of inorganic and organic nitrogen and efficiency in potato systems. Soil Sci. Soc. Am. J., 71: 1508-1515.

Olsen, S. R., and L. E. Sommers. 1982. Phosphorus. In: Page, A. L., R. H. Miller, and D. R. Keeney (Eds.). Methods of Soil Analysis. Part 2, Amer. Soc. Agron., Madison, W. I., USA, pp. 403-430

Pack, J. E. 2004. Controlled release nitrogen fertilizer release characterization and its effects on potato (Solanum tuberosum) production and soil nitrogen movement in northeast Florida. M. Sc. Thesis, Florida Univ., $136 \mathrm{p}$

Page, A. L. 1982. Methods of Soil Analysis. $2^{\text {nd }}$ Ed., Part 1, Soil Sci. Soc. Amer., Madison, Wisc., USA.

Shaviv, A. 2001. Advances in controlled-release fertilizers. Advances Agron., $71,1-49$.

Snedecor, G. W., and W. G. Cochran. 1982. Statistical Methods. $7^{\text {th }}$ Ed. $2^{\text {nd }}$ Printing, lowa State. Univ. Press, Ame., USA, pp 507.

Steel, R. G. D., and Torrie, J. H. 1980. Principles and Procedures of Statistics. A Biometrical Approach. $2^{\text {nd }}$ Ed. McGraw-Hill Publishing Co., New York, USA.

Tartoura, E. A. A., M. A. El-Saei, E. M. El-Said and G. A. Baddour. 2003. Suppressing the nitrate pollution in plant and soil using a clean performance in N-fertilization on potato. J. Envir. Sci., 25: 313-331.

Sullivan, J., W. G. Gabelman, and G. G. Gerloff. 1974. Variation in efficiency of nitrogen utilization in tomatoes grown under nitrogen stress. J. Amer. Soc. Hort. Sci., 99: 543-547.

Waddell, J. T., S. C. Gupta, J. F. Moncrief, C. J. Rosen, and D. D. Steele. 1999. Irrigation and nitrogen management effects on potato yield, tuber quality and nitrogen uptake. Agron. J., 91: 991-997. 
Worthington, C. M., K. M. Portier, J. M. White, R. S. Mylavarapu, T. A. Obreza, W. M. Stall, and C. M. Hutchinson. 2007. Potato (Solanum tuberosum L.) yield and internal heat necrosis incidence under controlled-release and soluble nitrogen sources and leaching irrigation events. Amer. J. Potato Res., 84: 403-413.

Zvomuya, F., C. R. Rosen, M. P. Russelle, and S. C. Gupta. 2003. Nitrate leaching and nitrogen recovery following application of polyolefincoated urea to potato. J. Environ. Qual., 32: 480-489.

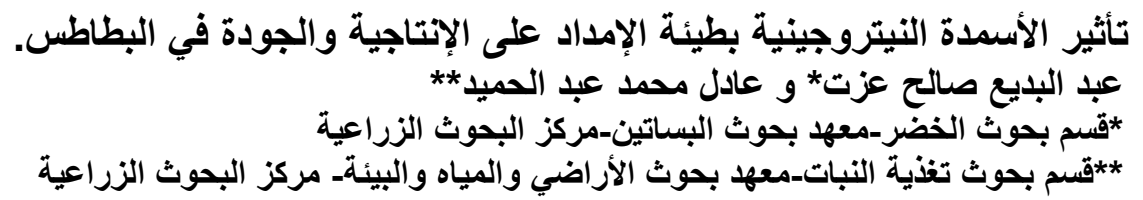

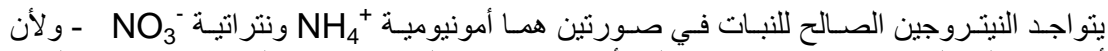

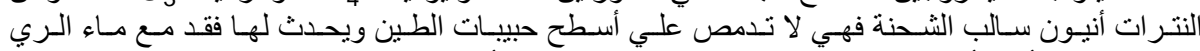

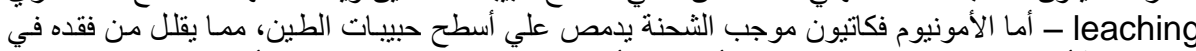

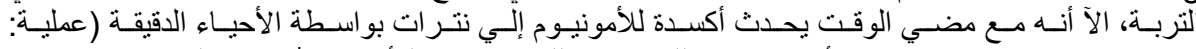

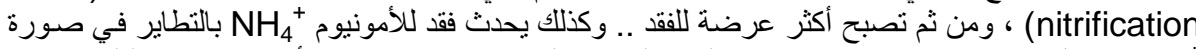

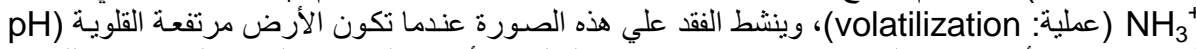

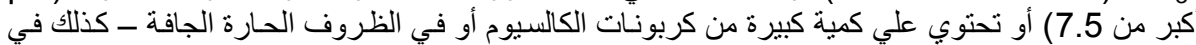

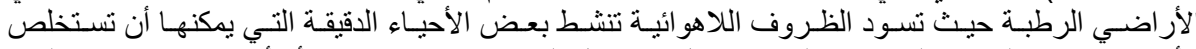

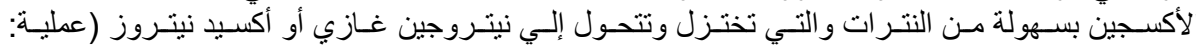
(denitrification

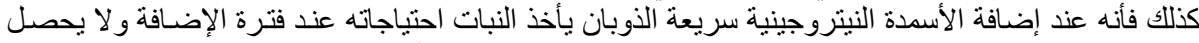

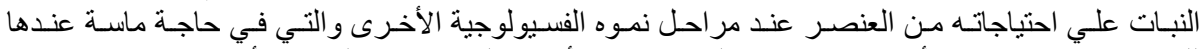

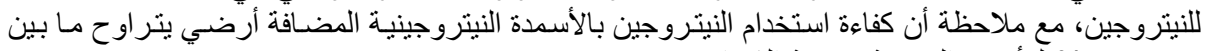
كا 60 : 60 \% للأسمدة المعدنية سريعة الذوبان.

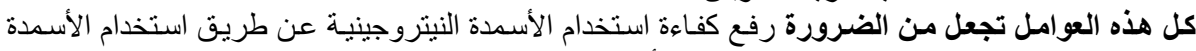

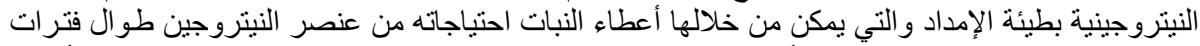

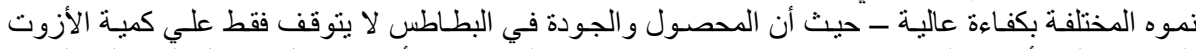

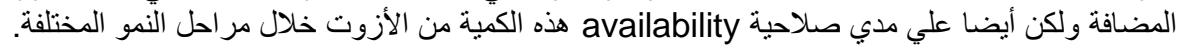

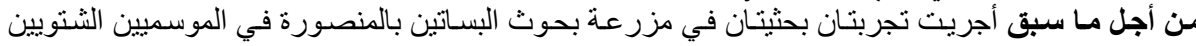

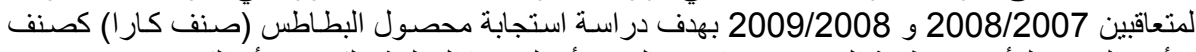

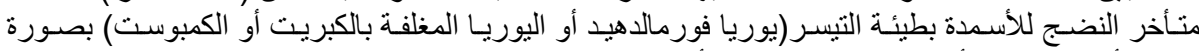

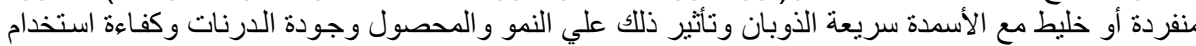

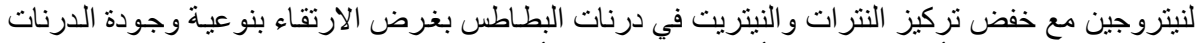

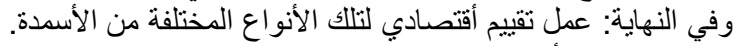

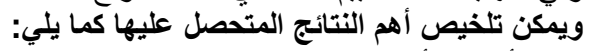

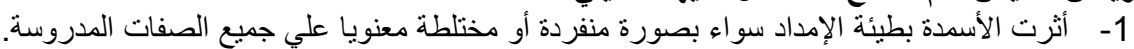

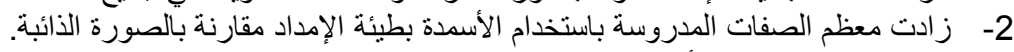

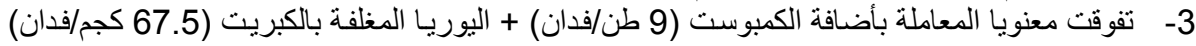

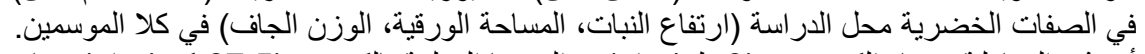

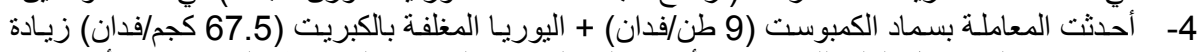

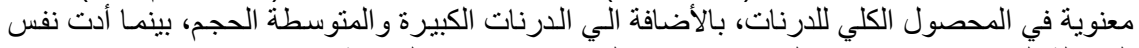
المعاملة التي نقص معنوي في الدرنات صغيرة الحجم في موسمي الدراسة. 
Ezzat, A. S. et al.

5- أدي استخدام سماد الكمبوست (9 طن/فدان) + اليوريا المغلفة بالكبريت (67.5 كجم/فدان) إلي زيادة معنوية في نسبة المادة الجافة للارنات في كلا الموسمين، وكنلك الكثافة النوعية ونسبة النثا (في الموسم (الأول فقط).

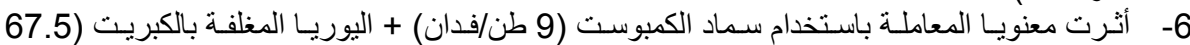

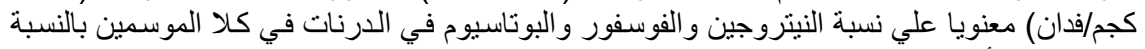

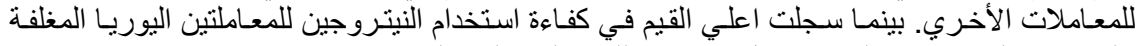

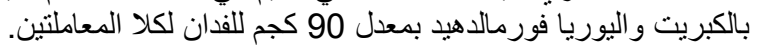

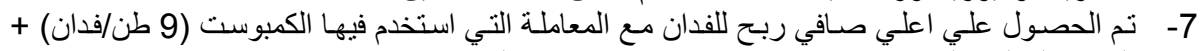

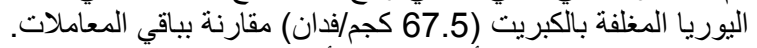

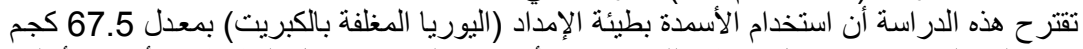

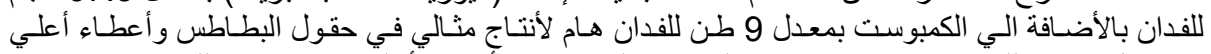

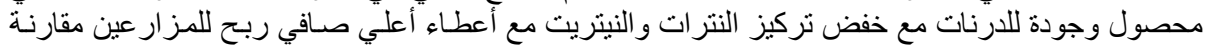
بالمعدل الموصي بله من السماد الكيماوي.

كلية الزراعة - جامعة المنصورة كلية الزراعة - جامعة الزقازيق
قام بتحكيم البحث

أ.د / أدمد / محد وجدي محمد العجرودي

أ.د / السيد عوض محمد عوض لمدي مجردي 
Table 5: Tuber qality of potato as affected by slow and soluble $\mathrm{N}$-fertilizers in 2007/08 and 2008/09 seasons.

\begin{tabular}{|c|c|c|c|c|c|c|c|c|c|c|}
\hline \multirow{3}{*}{\begin{tabular}{|l}
\multicolumn{2}{|c|}{ Characters } \\
Treatments \\
1- Ammonium nitrate (AN) $\left(180 \mathrm{~kg} \mathrm{~N}\right.$ fed. $\left.^{-1}\right)$,
\end{tabular}} & \multicolumn{2}{|c|}{$\begin{array}{l}\text { Tuber dry } \\
\text { matter (\%) }\end{array}$} & \multicolumn{2}{|c|}{ Starch (\%) } & \multicolumn{2}{|c|}{ Specific gravity } & \multicolumn{2}{|c|}{$\begin{array}{c}\text { Nitrate content } \\
\text { (mg/kg F.W.) }\end{array}$} & \multicolumn{2}{|c|}{$\begin{array}{l}\text { Nitrite content } \\
\text { (mg/kg F.W.) }\end{array}$} \\
\hline & $2007 / 08$ & $2008 / 09$ & $2007 / 08$ & $2008 / 09$ & $2007 / 08$ & $2008 / 09$ & $2007 / 08$ & $2008 / 09$ & $2007 / 08$ & 2008/09 \\
\hline & 20.862 & 20.213 & 14.65 & 14.30 & 1.0885 & 1.0798 & 65.30 & 68.23 & 0.62 & 0.58 \\
\hline 2- Compost (18 ton fed..$\left.^{-1}\right)$ & 21.400 & 21.196 & 15.38 & 15.23 & 1.0962 & 1.0842 & 34.71 & 24.86 & 0.24 & 0.28 \\
\hline 3- Urea formaldehyde (UF1); $135 \mathrm{~kg} \mathrm{~N}$ fed. $^{-1}$ & 21.665 & 21.630 & 15.17 & 14.93 & 1.0918 & 1.0815 & 46.13 & 46.67 & 0.42 & 0.54 \\
\hline 4- Urea formaldehyde (UF2); $90 \mathrm{~kg} \mathrm{~N}$ fed. $^{-1}$ & 20.793 & 19.981 & 14.13 & 14.63 & 1.0824 & 1.0823 & 51.74 & 49.23 & 0.48 & 0.46 \\
\hline 5-Sulfur coated urea (SCU1); $135 \mathrm{~kg} \mathrm{~N}$ fed. $^{-1}$ & 22.520 & 21.180 & 15.73 & 15.10 & 1.0992 & 1.0833 & 50.00 & .13 & 0.50 & 0.43 \\
\hline 6-Sulfur coated urea (SCU2); $90 \mathrm{~kg} \mathrm{~N}$ fed. $^{-1}$ & 21.800 & 20.840 & 14.41 & 14.82 & 1.0855 & 1.0730 & 49.25 & 40.81 & 0.40 & 0.48 \\
\hline 7- AN $90 \mathrm{~kg}+$ UF3 $67.5 \mathrm{~kg} \mathrm{~N}$ fed. $^{-1}$ & 19.364 & 19.741 & 12.88 & 13.80 & 1.0713 & 1.0752 & 63.00 & 66.32 & 0.55 & 0.57 \\
\hline 8- AN $90 \mathrm{~kg}+$ UF4 $45 \mathrm{~kg} \mathrm{~N}_{\text {fed. }}^{-1}$ & 19.382 & 19.801 & 13.64 & 12.87 & 1.0788 & 1.0740 & 62.18 & 65.20 & 0.53 & 0.53 \\
\hline 9- AN $90 \mathrm{~kg}+\mathrm{SCU}_{3} 67.5 \mathrm{~kg} \mathrm{~N}_{\text {fed. }^{-1}}$ & 20.171 & 19.821 & 13.50 & 13.30 & 300 & 1.0813 & 58.80 & 63.78 & 0.58 & 0.55 \\
\hline 10- AN $90 \mathrm{~kg}+\mathrm{SCU}_{4} 45 \mathrm{~kg} \mathrm{~N}^{-1}$ fed. $^{-1}$ & 19.442 & 19.630 & 12.94 & 12.65 & & & 54.30 & 62.37 & 0.51 & 0.51 \\
\hline 11-Compost 9 ton + UF3 67 & 21.180 & 21.283 & 14.80 & 12.53 & 1.0894 & 1.0723 & 38.65 & 39.40 & 0.31 & 0.32 \\
\hline 12-Compost 9 & 20.940 & & 14.02 & & & & 35.70 & & 0.38 & 0.40 \\
\hline 13-Compost 9 & 21.840 & & & 15.33 & & & 24.80 & 25.13 & 0.27 & 0.30 \\
\hline 14-Compost 9 & & & & 13.61 & & & & 32.22 & 0.30 & 0.38 \\
\hline LSD at 0.05 level & 0.264 & 0.551 & 0.02 & NS & 0.0045 & NS & 2.05 & 5.02 & 0.02 & 0.05 \\
\hline
\end{tabular}

